\title{
AYOTZINAPA, GUERRERO: IMAGE OF THE CORRUPTION AND IMPUNITY IN MEXICO
}

\begin{abstract}
Following the case of the disappearance of the 43 Ayotzinapa students, the Pandora's Box was opened: pits filled with bodies, corruption, impunity and institutional weakness of a state where politicians, police and authorities at all three government levels have been infiltrated by the organized crime. In Mexico, corruption and drug trafficking are common and the economic reforms are not enough if they do not go together with an effective program of combating corruption and the society is not the main beneficiary of the reforms.

This article will explain the background of the Ayotzinapa case, the characteristics of the Mexican political system that allow cases like Ayotzinapa, the consequences of the fight against organized crime launched by ex-President Felipe Calderon, the behavior of a sleeping civil society tired of the reduced economic results and where the state does not have the monopoly of the authority and does not guarantee security.
\end{abstract}

\section{Key words}

corruption, impunity, reforms, violence, disappearances, organized crime

\section{Introduction}

On September 26, 2014, in the city of Iguala, in the State of Guerrero, municipal policemen murdered six people and other armed men, amongst them three students from the Normal Rural de Ayotzinapa School, and 43 people "disappeared". The investigations exposed the complicity between the organized crime and the state and municipal authorities. Since then, there are protests and civic

\footnotetext{
* Yoanna Shubich Green, Universidad Anáhuac, Mexico.
} 